\title{
TRANSFORAMINAL CERVICAL NERVE ROOT BLOCK: OUTCOMES AND COMPLICATIONS
}

\author{
BLOQUEIO TRANSFORAMINAL CERVICAL: RESULTADOS E COMPLICAÇÕES \\ BLOQUEO TRANSFORAMINAL CERVICAL: RESULTADOS Y COMPLICACIONES
}

Emiliano Neves Vialle", Luiz Roberto Gomes Vialle", Joana Bretas Cabral Rondon Guasoue ${ }^{1}$

1. Pontifícia Universidade Católica, Hospital Universitário Cajuru, Spine Surgery Group, Curitiba, PR, Brazil.

\begin{abstract}
Objectives: To investigate the effect and complications after transforaminal injection for cervicobrachialgia caused by cervical disc herniation. Methods: We retrospectively reviewed all patients undergoing fluoroscopy-guided transforaminal injection for radiculopathy caused by cervical disc herniation. During the last seven years, 57 patients (39 female, 18 male, mean age 45.6 years) experiencing cervical radiculopathy underwent cervical foraminal block guided by fluoroscopy by postero-lateral approach. The position of the needle was verified after injection of a small amount of contrast. A glucocorticosteroid was injected after $0.5 \mathrm{ml}$ of 2\% lidocaine. Results: The local with the highest prevalence of procedures was C6 root (31 procedures); 14 patients underwent C7 block, 7 had C5 block, and 5 in C4. Eight patients (14\%) had complications (3 syncopes, 3 transient hoarseness, one patient had worsening of symptoms and one patient had soft tissue hematoma). In total, $42.1 \%$ were asymptomatic after the procedure and therefore did not require surgery after the procedure. Other $57.9 \%$ had transient improvement, became asymptomatic for at least 2 months but required surgery due to the recurrence of symptoms. Conclusion: Cervical foraminal block for cervical disc herniation is a safe way to avoid surgery. Some patients still need surgery after the procedure, but the temporary improvement in symptoms gives the patient some relief while awaiting surgery.
\end{abstract}

Keywords: Intervertebral disc displacement; Radiculopathy; Nerve block; Treatment outcome; Neck pain.

\section{RESUMO}

Objetivos: Investigar o efeito e as complicações depois de infiltração transforaminal para cervicobraquialgia causada por hérnia de disco cervical. Métodos: Foram analisados retrospectivamente todos os pacientes submetidos à infiltração transforaminal guiada por fluoroscopia para radiculopatia causada por hérnia de disco cervical. Durante os últimos sete anos, 57 pacientes (39 do sexo feminino, 18 do sexo masculino, com média de idade de 45,6 anos) com radiculopatia cervical foram submetidos a bloqueio foraminal cervical guiado por fluoroscopia por abordagem póstero-lateral. Verificou-se a posição da agulha após injeção de uma pequena quantidade de contraste. Um glicocorticosteroide foi injetado depois de 0,5 m/ de lidocaína a $2 \%$. Resultados: O local com maior prevalência de procedimentos foi a raiz de C6 (31 procedimentos); 14 pacientes foram submetidos a bloqueios de C7, 7 pacientes de C5 e 5 pacientes de C4. Oito pacientes (14\%) apresentaram complicações (3 síncopes, 3 pacientes apresentaram rouquidão transitória, um paciente teve piora dos sintomas e um paciente evoluiu com hematoma de partes moles). Do total, 42, 1\% tornaram-se assintomáticos e, portanto, não necessitaram tratamento cirúrgico após o procedimento. Outros 57,9\% tiveram melhora transitória, tornaram-se assintomáticos por no mínimo 2 meses, mas necessitaram cirurgia pelo retorno dos sintomas. Conclusão: O bloqueio radicular para hérnia de disco cervical é uma maneira segura de evitar cirurgia. Alguns pacientes ainda precisam de cirurgia após o procedimento; no entanto, a melhora transitória dos sintomas viabiliza uma espera menos sintomática para o paciente até a realização da cirurgia.

Descritores: Deslocamento do disco intervertebral; Radiculopatia; Bloqueio nervoso; Resultado do tratamento; Cenvicalgia.

\section{RESUMEN}

Objetivos: Investigar el efecto y las complicaciones después de la infiltración transforaminal para la cervicobraquialgia causada por hernia de disco cervical. Métodos: Se revisaron retrospectivamente todos los pacientes sometidos a la infiltración transforaminal guiada por fluoroscopia para radiculopatía causada por hernia de disco cervical. Durante los últimos siete años, 57 pacientes (39 mujeres, 18 hombres, edad media 45,6 años) con radiculopatía cervical fueron sometidos a bloqueo foraminal cervical guiado por fluoroscopia mediante abordaje posterolateral. La posición de la aguja se observó después de la inyección de una pequeña cantidad de contraste. Un glucocorticosteroide fue inyectado después de 0,5 m/ de lidocaína al $2 \%$. Resultados: El sitio de prevalencia más alta de procedimientos fue la raíz de C6 (31 procedimientos); 14 pacientes fueron sometidos a bloqueos de C7, 7 pacientes de C5 y 5 pacientes de C4. Ocho pacientes (14\%) tuvieron complicaciones (3 síncopas, 3 pacientes presentaron ronquera transitoria, un paciente presentó empeoramiento de los síntomas y un paciente tuvo hematoma de tejidos blandos). Del total, el 42,1\% eran asintomáticos y por lo tanto, no requirieron tratamiento quirúrgico después del procedimiento. Los otros $57,9 \%$ tuvieron una mejoría transitoria, convirtiéndose en asintomáticos durante al menos dos meses, sin embargo, requirieron cirugía debido a la recurrencia de los síntomas. Conclusión: El bloqueo de la raíz para la hernia de disco cervical es una forma segura de evitar la cirugía. Algunos 
pacientes todavía necesitan cirugía después del procedimiento; sin embargo, la mejoría transitoria de los síntomas permite un tiempo de espera menos sintomático antes de la realización de la cirugía.

\section{Descriptores: Desplazamiento del disco intervertebral; Radiculopatía; Bloqueo nervioso; Resultado del tratamiento; Dolor de cuello.}

\section{INTRODUCTION}

Cervicobrachialgia is frequently encountered in clinical practice. Foraminal stenosis associated with spondylosis (70-75\%) and disc herniation (20-25\%) are the primary causes. ${ }^{1}$ Even though it is an incapacitating condition, the natural history of the disease is favorable. The literature shows that, in the long term, conservative treatment is better than surgery, ${ }^{2,3}$ with surgery being indicated only in patients who do not respond to clinical management. Transforaminal cervical block is an alternative to surgical treatment, but there are several reports of serious complications in patients who undergo this procedure, such as spinal cord infarction and death. ${ }^{4-7}$

The objective of this study is to assess the results and the complications of this procedure in our service in patients with cervicobrachialgia due to disc herniation.

\section{METHODS}

This was a retrospective review of medical records. The inclusion criteria were: patients who underwent transforaminal nerve root block (TNRB) for cervicobrachialgia caused by cervical disc herniation from August 2007 to August 2014. All the patients underwent prior conservative treatment, including physical therapy, cervical traction, and oral medications, for a minimum of 4 weeks. The block was indicated for patients when initial conservative management failed. A total of 57 patients (39 female and 18 male) underwent the procedure. The average age was 45.6 years (ranging from 34 to 60 years of age). The medical report data evaluated were: the cervical level affected, the clinical improvement, asymptomatic period after the block, the need for surgical treatment following the block, the time interval between the block and the surgery, and post-block complications.

The blocks were performed by the same surgeon using the following technique: the patient was positioned in dorsal decubitus with a slight cervical extension. The location was confirmed using an image intensifier in both anterior-posterior and profile views. (Figures 1 and 2) A contrast agent (iohexol $300 \mathrm{mg} \mathrm{l} / \mathrm{mL}$ ) was injected using a 25x90mm needle to confirm the location and extravascular positioning. After radioscopic confirmation of the proper positioning of the needle, $0.5 \mathrm{ml}$ of $2.0 \%$ lidocaine and $0.5 \mathrm{ml}$ of $4 \mathrm{mg} / \mathrm{mL}$ betamethasone were injected.

The data obtained are part of a project approved by the Institutional Review Board as number 21350513.1.0000.0020.

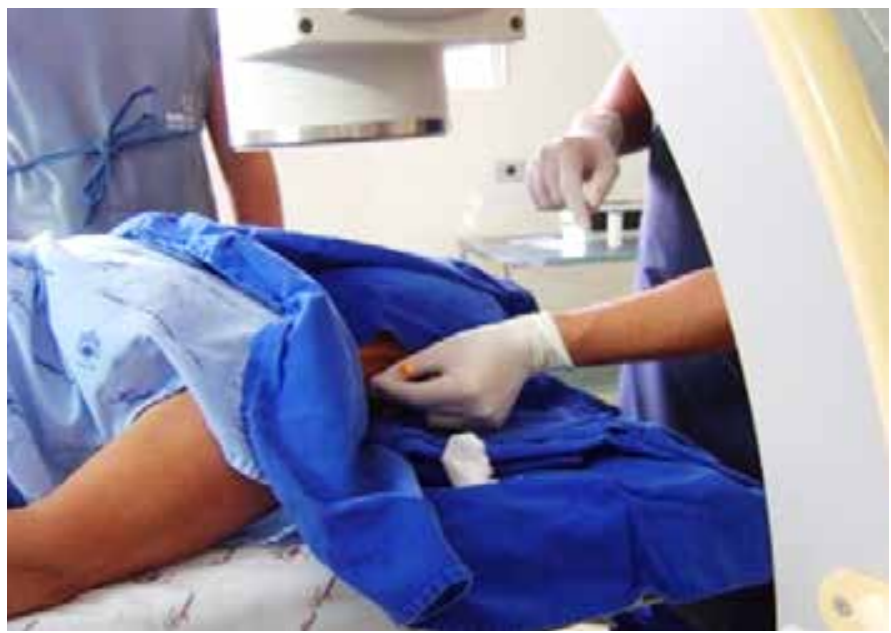

Figure 1. Positioning of the needle perpendicular to the cervical spine.

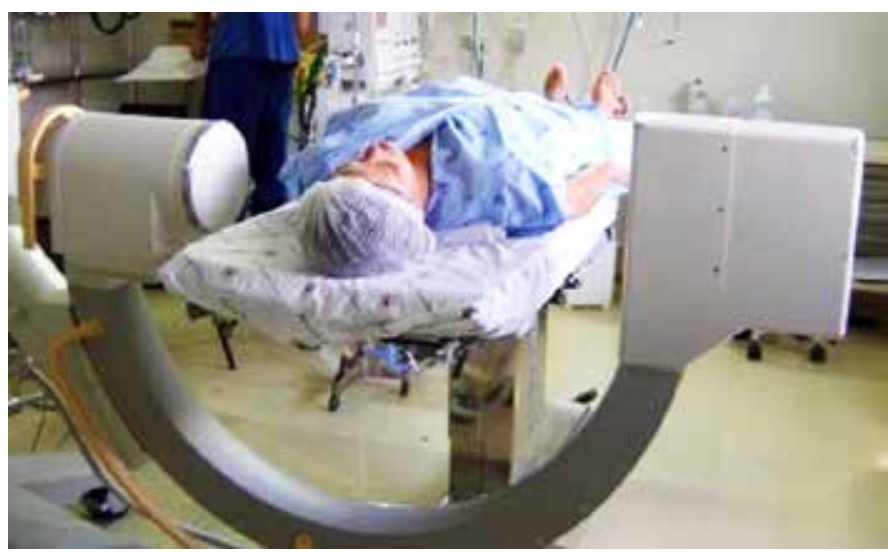

Figure 2. Positioning of the patient on a radiotransparent table with the cervical spine in extension.

\section{RESULTS}

The most common location for the procedure was the nerve root of C6 (31 procedures), followed by the root of C7 (14 patients), the root of C5 (7 procedures), and of C4 (5 patients).

Of the patients, $42.1 \%$ became asymptomatic in the long term following the procedure, therefore did not require surgery, and had complete remission of the cervicobrachialgia. Another $45.6 \%$ improved for a period of at least two months, however, their symptoms returned and surgery was indicated to resolve the condition. Seven patients (12.3\%) did not improve following the procedure and later opted for surgical treatment.

No serious complications such as death, paralysis, cerebral vascular accidents, or lesions of the vertebral artery were observed. However, $14 \%$ of the patients had minor complications. Three patients had syncope after the procedure, three had temporary hoarseness, one patient developed a soft tissue hematoma, and another patient had worsening of symptoms following the procedure.

\section{DISCUSSION}

Compared to interlaminar epidural injections, transforaminal epidural block provides better distribution of the medication in the treatment of radiculopathy. However, an accidental intravascular injection, especially in the vertebral artery, can cause catastrophic complications. One of the hypotheses proposed as the cause of cerebral and medullary infarctions is the inadvertent intra-arterial infiltration of particulate corticosteroids, which could cause the formation of an embolism leading to ischemia. ${ }^{8-10}$ The corticosteroid with the largest particles is methylprednisolone so it should not be used for a transforaminal cervical nerve root block (TNRB). The drug of choice is betamethasone. Even though it is a particulate (which means it has a greater half-life), there was only one case of a serious complication among the 1340 blocks evaluated in the study by Scanlon et al. ${ }^{11}$ Another determining factor in preventing intravascular injection is the use of a contrast agent prior to using corticosteroids. The aspiration maneuver with a syringe to confirm the extra-vascular positioning has a $19.4 \%$ incidence of false negatives. ${ }^{12}$

Lidocaine (medium potency) was used instead of high-potency bupivacaine to prevent a total spinal block in cases of perforation of the dura mater, in addition to using the anesthetic before the corticosteroid to prevent irreversible neurological damage.

For most of the patients analyzed, the cervical block was beneficial $(87.7 \%)$ and almost half of these $(48 \%)$ had no new 
symptoms. The other half experienced a remission of symptoms for a minimum of two months, which facilitated the wait for surgery. None of the small percentage of patients who experienced complications had complications resulting from the procedure.

\section{CONCLUSION}

Transforaminal cervical block is a method to avoid surgical treatment in cases that do not respond to conservative treatment of cervicobrachialgia caused by disc herniation. By taking the proper precautions, the risk of complications, especially serious ones, can be minimized.

All authors declare that there are no potential conflicts of interest regarding this article.

CONTRIBUTIONS OF THE AUTHORS: Each author made significant individual contributions to the development of this manuscript. ENV performed the surgical procedures and data collection. ENV, LRGV, and JBCRG wrote and revised the manuscript. All the authors contributed to the intellectual concept of the study.

\section{REFERENCES}

1. Radhakrishnan K, Litchy WJ, O'Fallon WM, Kurland LT. Epidemiology of cervical radiculopathy. A population-based study from Rochester, Minnesota, 1976 through 1990. Brain. 1994;117 (Pt 2):325-35.

2. Heckmann JG, Lang CJ, Zöbelein I, Laumer R, Druschky A, Neundörfer B. Herniated cervical intervertebral discs with radiculopathy: an outcome study of conservatively or surgically treated patients. J Spinal Disord. 1999;12(5):396-401.

3. Saal JS, Saal JA, Yurth EF. Nonoperative management of herniated cervical intervertebral disc with radiculopathy. Spine (Phila Pa 1976). 1996;21(16):1877-83.

4. Brouwers PJ, Kottink EJ, Simon MA, Prevo RL. A cervical anterior spinal artery syndrome after diagnostic blockade of the right C6-nerve root. Pain. 2001;91(3):397-9.

5. Ludwig MA, Burns SP. Spinal cord infarction following cervical transforaminal epidural injection: a case report. Spine (Phila Pa 1976). 2005:30(10):E266-8.

6. Rozin L, Rozin R, Koehler SA, Shakir A, Ladham S, Barmada M, et al. Death during transforaminal epidural steroid nerve root block (C7) due to perforation of the left vertebral artery. Am J Forensic Med Pathol. 2003;24(4):351-5.

7. Meyer HJ, Monticelli F, Kiesslich J. Fatal embolism of the anterior spinal artery after local cervical analgetic infiltration. Forensic Sci Int. 2005;149(2-3):115-9.

8. Tiso RL, Cutler T, Catania JA, Whalen K. Adverse central nervous system sequelae after selective transforaminal block: the role of corticosteroids. Spine J. 2004:4(4):468-74.

9. Baker R, Dreyfuss P, Mercer S, Bogduk N. Cervical transforaminal injection of corticosteroids into a radicular artery: a possible mechanism for spinal cord injury. Pain. 2003;103(1-2):211-5.

10. Rathmell JP, Aprill C, Bogduk N. Cervical transforaminal injection of steroids. Anesthesiology. 2004;100(6):1595-600.

11. Scanlon GC, Moeller-Bertram T, Romanowsky SM, Wallace MS. Cervical transforaminal epidural steroid injections: more dangerous than we think? Spine (Phila Pa 1976). 2007 ;32(11):1249-56.

12. Furman MB, Giovanniello MT, O'Brien EM. Incidence of intravascular penetration in transforaminal cervical epidural steroid injections. Spine (Phila Pa 1976). 2003;28(1):21-5. 